\title{
Preventing cognitive decline in preclinical Alzheimer's disease
}

Citation for published version (APA):

Riedel, W. J. (2014). Preventing cognitive decline in preclinical Alzheimer's disease. Current Opinion in Pharmacology, 14, 18-22. https://doi.org/10.1016/j.coph.2013.10.002

Document status and date:

Published: 01/01/2014

DOI:

10.1016/j.coph.2013.10.002

Document Version:

Publisher's PDF, also known as Version of record

Document license:

Taverne

Please check the document version of this publication:

- A submitted manuscript is the version of the article upon submission and before peer-review. There can be important differences between the submitted version and the official published version of record.

People interested in the research are advised to contact the author for the final version of the publication, or visit the DOI to the publisher's website.

- The final author version and the galley proof are versions of the publication after peer review.

- The final published version features the final layout of the paper including the volume, issue and page numbers.

Link to publication

\footnotetext{
General rights rights.

- You may freely distribute the URL identifying the publication in the public portal. please follow below link for the End User Agreement:

www.umlib.nl/taverne-license

Take down policy

If you believe that this document breaches copyright please contact us at:

repository@maastrichtuniversity.nl

providing details and we will investigate your claim.
}

Copyright and moral rights for the publications made accessible in the public portal are retained by the authors and/or other copyright owners and it is a condition of accessing publications that users recognise and abide by the legal requirements associated with these

- Users may download and print one copy of any publication from the public portal for the purpose of private study or research.

- You may not further distribute the material or use it for any profit-making activity or commercial gain

If the publication is distributed under the terms of Article $25 \mathrm{fa}$ of the Dutch Copyright Act, indicated by the "Taverne" license above, 


\section{Preventing cognitive decline in preclinical Alzheimer's disease Wim J Riedel ${ }^{1,2,3}$}

\begin{abstract}
Alzheimer's disease (AD) is a chronic neurodegenerative disease leading to cognitive decline, dementia, and ultimately death. Despite extensive R\&D efforts, there are no diseases modifying treatments for $A D$ available. The stage in which patients receive a clinical diagnosis of probable AD may be too late for disease modifying pharmacotherapy. Prevention strategies may be required to successfully tackle AD.Preclinical $A D$ applies to over half of all healthy elderly subjects and manifests by signs of amyloid deposition and/or neuronal injury in the brain, preceding the stage in which symptoms of dementia, cognitive and functional impairment become observable. Prevention trials in preclinical $A D$ require longer and larger clinical trials using biomarkers and cognitive endpoints, which requires collaboration across academia, government and industry.

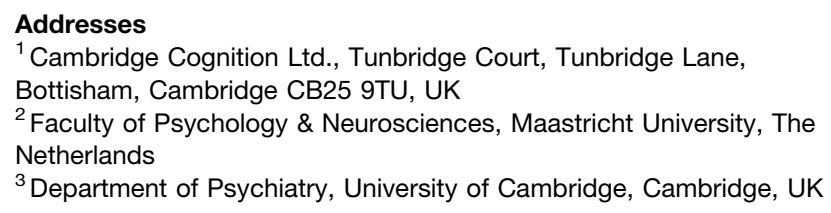

\section{Introduction}

Alzheimer's disease (AD) is the most common neurodegenerative condition. Currently 35 million patients suffer from $\mathrm{AD}$ and this number is estimated to rise to 115 million patients worldwide by 2050 [1,2]. At microscopic level, AD is characterized by the presence of large numbers of neuritic plaques, neurofibrillary tangles and by neuronal cell loss beginning in the hippocampus [3]. Clinically AD manifests itself by progressive decline of memory and other cognitive functions. Mild cognitive impairment (MCI) is considered to reflect a transitional stage between normal aging and dementia [4].

Recently, an asymptomatic phase, preclinical AD, has been defined as the stage preceding MCI and AD [5,6]. Subjects in the preclinical stage are at risk for $\mathrm{AD}$, as shown by biomarkers signaling amyloid deposition in the brain (low amyloid-beta in cerebrospinal fluid [CSF] or increased binding to amyloid ligands in positron emission tomography [PET]) and signs of neuronal injury, such as high tau or phospho-tau in CSF, as well as signs of cortical thinning and hippocampal atrophy on structural magnetic resonance imaging (MRI) [7].

At present, five stages describe the potential recognition of approx. $96 \%$ of all healthy older adults ( $>65$ years) $54 \%$ of whom are at risk developing AD before they express MCI, based on assessment of amyloid accumulation in the brain in the first stage, signs of neuronal injury in the second stage and subtle cognitive impairment in the third stage $\left[9^{\bullet \bullet}\right.$ ] (see Table 1$)$.

\section{Preclinical Alzheimers disease}

The categorization of preclinical AD is based on new research criteria commissioned by the National Institute on Aging and the Alzheimer's Association (NIA-AA), which distinguish three advancing stages (1-3) of preclinical AD from normality (stage 0) [6] in addition to the description of Suspected Non-AD Pathophysiology (SNAP) and a remaining unclassified category [ $\left.9^{\bullet}\right]$. SNAP is defined by presence of neuronal injury markers and absence of amyloid with or without signs of cognitive impairment. The unclassified category is defined by presence of subtle cognitive impairment and absence of amyloid with or without markers of neuronal injury. The stages at which cognitive and behavioral symptoms become manifest, are MCI and probable AD. The latter represents what is known in NINCDS ADRDA as clinical diagnosis of probable AD. Prodromal MCI is defined as clinically abnormal performance on tests of episodic memory along with evidence of amyloid deposition in the brain [11].

Vos et al. $\left[10^{\bullet \bullet}\right]$ describe a longitudinal study carried out at the Knight Alzheimer's Disease Research Center (KADRG) at Washington University in St. Louis, Missouri, of 311 cognitively normal elderly people. Participants were older than 65 and had a Clinical Dementia Rating (CDR) of 0 at baseline, indicating normal cognition. Amyloid pathology and neurodegeneration were assessed from CSF, measured by amyloid-beta and tau, respectively. The results of classification into stages of preclinical AD was very similar to that reported by the Mayo Clinic Study of Aging (MCSA) in a separate population of cognitively healthy older adults using amyloid imaging. The average of these classifications are shown in Table 1. These studies show that preclinical $\mathrm{AD}$ is common and can be diagnosed by markers in CSF $\left[9^{\bullet \bullet}, 10^{\bullet \bullet}\right]$. A strong association was shown between 


\begin{tabular}{|c|c|c|c|c|c|c|c|}
\hline \multicolumn{8}{|c|}{ Characterization of stages from normality to $A D$} \\
\hline \multirow[t]{2}{*}{ Condition } & \multirow[t]{2}{*}{ Stage } & \multirow{2}{*}{$\begin{array}{c}\text { Avg. \% in } \\
\text { cohort studies }\end{array}$} & \multicolumn{2}{|c|}{ Molecular biomarkers } & \multirow{2}{*}{$\begin{array}{l}\text { Cognitive } \\
\text { impairment }\end{array}$} & \multirow{2}{*}{$\begin{array}{c}\text { Clinical } \\
\text { Dementia Rating }\end{array}$} & \multirow{2}{*}{$\begin{array}{c}\text { Years to } \\
\text { probable } A D[8]\end{array}$} \\
\hline & & & Amyloid deposition & $\overline{\text { Neuronal Injury }}$ & & & \\
\hline Normal & Stage 0 & $42 \%$ & - & - & - & 0 & \\
\hline \multirow[t]{5}{*}{ Preclinical $A D$} & Stage 1 & $15.5 \%$ & + & - & - & 0 & $17-23$ \\
\hline & Stage 2 & $12 \%$ & + & + & - & 0 & $7-13$ \\
\hline & Stage 3 & $3.5 \%$ & + & + & + & 0 & $6-10$ \\
\hline & SNAP & $23 \%$ & - & + & $-/+$ & 0 & \\
\hline & Unclassified & $4 \%$ & - & $-/+$ & + & 0 & \\
\hline Prodromal AD & \multicolumn{2}{|c|}{$\mathrm{MCl}$ due to $A D$} & + & + & + & 0.5 & $5-8$ \\
\hline Probable AD & \multicolumn{2}{|c|}{ Mild to moderate $A D$} & $+1-$ & $+/-$ & + & $\geq 1$ & 0 \\
\hline
\end{tabular}

preclinical $\mathrm{AD}$ and future cognitive decline in both MCSA and KADRC studies $\left[10^{\bullet \bullet}, 12\right]$. The KADRC study also showed a strong association between preclinical AD and mortality and this adds to the importance of preclinical $\mathrm{AD}$ as a target for therapeutic intervention. Because of observed differences in rate of progression, it is argued that in prevention trials subjects can best be stratified by preclinical AD stage $\left[10^{\circ}\right]$.

\section{Clinical trials before Alzheimers disease}

In the past decades, clinical drug trials have been carried out in patients with mild to moderate $\mathrm{AD}$ and this has only yielded the currently registered drugs, the cholinesterase inhibitors and an NMDA blocker, which act at best symptomatic, that is, they temporarily stop or attenuate decline but do not halt it. Since recently, clinical trials of disease modifying agents are currently being carried out in prodromal AD. Although no clinical trials are known to date to be carried out in preclinical AD, the door to this has been opened by a recent new Food and Drug Administration (FDA) guidance on developing drugs for treatment of preclinical AD [13]. The possibility of clinical drug trials is suggested in subjects with only subtle cognitive deficits in the absence of any detectable functional impairment. An effect on a valid and reliable cognitive assessment used as a single primary efficacy measure would be considered for approval by FDA [14]. In relation to the staging descriptions above, this applies to subjects in preclinical $\mathrm{AD}$, in whom cognitive decline would be prevented. Decline can also be described as poor performance on more challenging cognitive tests [6]. The preclinical criteria emphasize memory. However, declines in other domains may be the initial cognitive signal of impending AD [15,16].

\section{Cognitive assessments}

The instrument hitherto most used to assess changes in cognition in trials in mild to moderate AD is the Cognitive subscale of the Alzheimers Disease Assessment Scale, or ADAS-Cog [17]. However, due to a restriction of range in test scores (ceiling-effect), it lacks sensitivity to detect changes in earlier stages such as MCI and preclinical AD [18]. The Clinical Dementia Rating scale, in particular its so-called Sum of Boxes score (CDR-SB), has been proposed as primary assessment instrument in prodromal $A D$ $\left[19^{\circ}\right]$. However, because of its expected value of zero in preclinical AD, CDR-SB is not expected to be targeting cognitive performance in that range. The studies in preclinical AD described here in the MCSA cohort $\left[9^{\bullet \bullet}\right]$ and in the KADRC cohort [10 $0^{\bullet \bullet}$, have used neuropsychological test batteries to detect signs of subtle cognitive impairment in stage 3 of preclinical AD. In both studies detection was set at scores below the 10th percentile, which resembled an approx. 1.25 SD deviation from reference values in normal controls. In the MCSA study a global composite cognitive score comprising the executive, language, visuospatial and memory domains, was used after it was established that a similar result would be obtained when using a memory domain score $\left[9^{\bullet \bullet}\right]$. In the KADRC study an episodic memory composite score was used as the measure of cognition to define

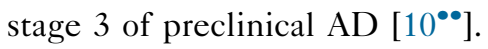

\section{Cognition and amyloid}

Although previous studies had observed only moderate negative relationships between amyloid-beta and cognition and/or episodic memory, a recent meta-analysis established a modest significant relationship between amyloid-beta and cognition [20]. In the Australian Imaging, Biomarker and Lifestyle (AIBL) study, more decline was reported in preclinical AD subjects with high amyloid-beta after 18 months on memory and language (fluency) and similar memory decline was also seen in individuals genetically at risk as determined by presence of a ApoE4 allele(s) $\left[21,22^{\circ}\right]$. These studies suggest that in preclinical $\mathrm{AD}$, elevated amyloid-beta load is associated with subtle $\mathrm{AD}$-related cognitive impairment. It was also concluded that the relationship between amyloidbeta and cognitive decline in preclinical $\mathrm{AD}$ may be best understood from prospective studies [21]. Data from prospective studies suggest that high amyloid-beta does increase the risk of progression to MCI [23], and that 
subtle decline in episodic memory, even in the absence of any change in clinical status, can be detected within 18 months [24].

\section{Cognitive diagnostic screening instruments}

Neuropsychological tests can facilitate the detection of subtle signs of cognitive impairment. Episodic memory tests have been shown effective to detect MCI and differentiate from $\mathrm{AD}\left[25^{\circ}\right]$. Because in preclinical $\mathrm{AD}$, subjects are functioning cognitively normal and at most show some subtle deficits, new technologies hold promise for wide-scale application in both detection as well as monitoring progression. Web-based testing shows promise in this respect and attempts for validation of web-based cognitive assessments are already undertaken in various contexts $\left[26^{\bullet \bullet}, 27,28\right]$. Although the unsupervised nature may introduce some new methodological challenges, the obvious advantages are, for example, firstly, increasing reliability by taking advantage of more frequent assessments and hence averaging out the occasional 'bad day' and finally, creating time for cognitive assessment rather than scheduling it at the end of an exhaustive hospital visit including blood and CSF sampling, MRI scanning, PET scanning, etc.

\section{Enabling early detection and intervention in (preclinical) AD: need for public-private collaborative research}

In clinical practice dementia diagnosis rates are low; less than half of people in the UK living with dementia actually receive a dementia diagnosis [29]. There is a need for diagnostic procedures in mainstream healthcare otherwise we develop treatments for early phase disease but the patients will not be identified. Timely diagnosis and intervention will have a positive impact on healthcare system resources, with or without disease modifying treatments $\left[30^{\circ}\right]$. However, trials may require thousands of patients and several years of observation. The scientific challenges range from identifying subjects at risk, clinical endpoints and biomarkers, and establish how to achieve prevention. A public-private collaborative approach may be required to enable efficient design and execution of clinical AD prevention trials. In the US, since 2005 the longitudinal Alzheimers Disease Neuroimaging Initiative (ADNI) has been validating the use of biomarkers and imaging for AD clinical trials and diagnosis [31]. In Australia, there is the AIBL study [32]. Within the European Union (EU), there is the DESCRIPA study on early AD diagnosis [33] and also the Innovative Medicine Initiative (IMI) consortia, such as the European Medical Information Framework (EMIF). One of IMI-EMIF's goals is to establish and qualify early biomarkers of AD that might be beneficial in early intervention trials. A new proposed consortium will be the European Platform to facilitate Proof of Concept trials to enable prevention in AD (IMI EPOC).
It aims to build registries of subjects at risk of $\mathrm{AD}$, to invite subjects to join a longitudinal natural history study to qualify and validate AD biomarkers and to invite a subset of these subjects to participate in a pharmacological intervention trial.

\section{Conclusions}

Preclinical AD is an important clinical category, which applies to more than half of the normal elderly population over 65 years of age. It is hoped that new disease modifying therapies will allow $\mathrm{AD}$ prevention trials. Novel pharmacological treatments now attempt to target beta amyloid production, tau aggregation and nerve regeneration. It is hoped that such treatments can have an impact on the underlying neurodegeneration of $\mathrm{AD}$ very early, or even before its onset [34], in preclinical AD. Clinical pharmacology safety studies such as the single and multiple ascending dose studies will remain the starting point in drug development, yet will probably move swiftly into an adaptive trial scheme [35,36]. Although it may be more difficult to implement an adaptive trial for $\mathrm{AD}$ than for breast cancer, unblinded adaptive trials like the I-SPY 2 [37] will be much more attractive for patients. However, initially blinding will almost certainly be required in a preventive AD trial. Even though biomarker cut-points to characterize subgroups such as stages $1-3$ in preclinical and prodromal AD stages have been described, these are not yet considered mainstream and also, placebo effects cannot be ruled out [38]. An adaptive trial design requires fast readouts so that treatment regimens can be adjusted during the trial; this will present a challenge for biomarkers or cognitive measures to provide early evidence of a treatment effect. The trajectory from preclinical AD to $\mathrm{AD}$ demands different types of markers at different stages. PET imaging of amyloid and CSF sampling of $A \beta$ yield biomarkers for stratification, yet their invasiveness and cost are limiting factors. Instead, non-invasive diagnostic markers - such as a blood-based biomarker — are highly desired [38]. Future trials could employ longitudinally validated web-based computerized cognitive tests as essential element of an evidence-based diagnosis of $\mathrm{AD}$ in the trajectory from preclinical $\mathrm{AD}$ to prodromal AD to probable AD. Attempts to build a large registry of volunteers have already started (e.g., see http://www.nia.nih.gov/alzheimers/features/new-alzheimers-prevention-registry-recruiting-250000-volunteers and http://www.endalznow.org). Cardinal elements of a registry would be repeated cognitive assessments over a longer period of time in combination with biomarker assessments of amyloid and tau.

\section{References and recommended reading}

Papers of particular interest, published within the period of review, have been highlighted as:

- of special interest

•• of outstanding interest 
1. Wimo A, Winblad B, Aguero-Torres H, von Strauss E: The magnitude of dementia occurrence in the world. Alzheimer Dis Assoc Disord 2003, 17:63-67.

2. Pillai JA, Cummings JL: Clinical trials in predementia stages of Alzheimer disease. Med Clin North Am 2013, 97:439-457.

3. Nelson PT, Alafuzoff I, Bigio EH, Bouras C, Braak H, Cairns NJ, Castellani RJ, Crain BJ, Davies P, Del Tredici K et al:: Correlation of Alzheimer disease neuropathologic changes with cognitive status: a review of the literature. J Neuropathol Exp Neurol 2012 71:362-381.

4. Petersen RC, Doody R, Kurz A, Mohs RC, Morris JC, Rabins PV, Ritchie K, Rossor M, Thal L, Winblad B: Current concepts in mild cognitive impairment. Arch Neurol 2001, 58:1985-1992.

5. Rowe CC, Ellis KA, Rimajova M, Bourgeat P, Pike KE, Jones G, Fripp J, Tochon-Danguy H, Morandeau L, O'Keefe G et al.: Amyloid imaging results from the Australian Imaging, Biomarkers and Lifestyle (AIBL) study of aging. Neurobiol Aging 2010, 31:1275-1283.

6. Sperling RA, Aisen PS, Beckett LA, Bennett DA, Craft S, Fagan AM, Iwatsubo T, Jack CR Jr, Kaye J, Montine TJ et al.: Toward defining the preclinical stages of Alzheimer's disease: recommendations from the National Institute on AgingAlzheimer's Association workgroups on diagnostic guidelines for Alzheimer's disease. Alzheimers Dement 2011, 7: 280-292.

7. Jicha GA, Abner EL, Schmitt FA, Kryscio RJ, Riley KP, Cooper GE Stiles N, Mendiondo MS, Smith CD, Van Eldik LJ et al.: Preclinical AD Workgroup staging: pathological correlates and potential challenges. Neurobiol Aging 2012, 33 622.e621-622.e616.

8. Villemagne VL, Burnham S, Bourgeat P, Brown B, Ellis KA Salvado O, Szoeke C, Macaulay SL, Martins R, Maruff P et al.: Amyloid beta deposition, neurodegeneration, and cognitive decline in sporadic Alzheimer's disease: a prospective cohort study. Lancet Neurol 2013, 12:357-367.

9. Jack CR Jr, Knopman DS, Weigand SD, Wiste HJ, Vemuri P -. Lowe V, Kantarci K, Gunter JL, Senjem ML, Ivnik RJ et al: : An operational approach to National Institute on AgingAlzheimer's Association criteria for preclinical Alzheimer disease. Ann Neurol 2012, 71:765-775.

A cross-sectional evaluation of the NIA-AA criteria for preclinical AD indicates that the 1-3 staging criteria of preclinical $A D$ coupled with stage 0 and SNAP categories classify $97 \%$ of cognitively normal subjects from a population-based sample, leaving only $3 \%$ unclassified.

10. Vos SJ, Xiong C, Visser PJ, Jasielec MS, Hassenstab J, Grant EA

- Cairns NJ, Morris JC, Holtzman DM, Fagan AM: Preclinical Alzheimer's disease and its outcome: a longitudinal cohort study. Lancet Neurol 2013, 12:957-965 http://dx.doi.org/10.1016/ S1474-4422(13)70194-7 Available online 4 September 2013, ISSN 1474-4422.

Preclinical AD is common in cognitively normal elderly people and is associated with future cognitive decline and mortality. Compared with individuals classed as normal, participants with preclinical AD had an increased risk of death after adjusting for covariates.

11. Dubois B, Feldman HH, Jacova C, Cummings JL, Dekosky ST, Barberger-Gateau P, Delacourte A, Frisoni G, Fox NC, Galasko D et al.: Revising the definition of Alzheimer's disease: a new lexicon. Lancet Neurol 2010, 9:1118-1127.

12. Knopman DS, Jack CR Jr, Wiste HJ, Weigand SD, Vemuri P Lowe V, Kantarci K, Gunter JL, Senjem ML, Ivnik RJ et al.: Shortterm clinical outcomes for stages of NIA-AA preclinical Alzheimer disease. Neurology 2012, 78:1576-1582.

13. Center for Drug Evaluation and Research (CDER): Guidance for Industry: Alzheimer's Disease: Developing Drugs for the Treatment of Early Stage Disease. Washington, DC: Dept. of Health and Human Services, Food and Drug Administration; 2013,

14. Kozauer N, Katz R: Regulatory innovation and drug development for early-stage Alzheimer's disease. N Engl J Med 2013, 368:1169-1171.

15. Albert MS, Moss MB, Tanzi R, Jones K: Preclinical prediction of AD using neuropsychological tests. J Int Neuropsychol Soc 2001, 7:631-639.
16. Storandt M, Mintun MA, Head D, Morris JC: Cognitive decline and brain volume loss as signatures of cerebral amyloid-beta peptide deposition identified with Pittsburgh compound B: cognitive decline associated with Abeta deposition. Arch Neurol 2009, 66:1476-1481.

17. Mohs RC, Knopman D, Petersen RC, Ferris SH, Ernesto C, Grundman M, Sano M, Bieliauskas L, Geldmacher D, Clark C et al.: Development of cognitive instruments for use in clinical trials of antidementia drugs: additions to the Alzheimer's Disease Assessment Scale that broaden its scope. The Alzheimer's Disease Cooperative Study. Alzheimer Dis Assoc Disord 1997, 11:S13-S21.

18. Harrison J, Minassian SL, Jenkins L, Black RS, Koller M, Grundman M: A neuropsychological test battery for use in Alzheimer disease clinical trials. Arch Neurol 2007, 64 1323-1329.

19. Cedarbaum JM, Jaros M, Hernandez C, Coley N, Andrieu S

- $\quad G r u n d m a n$ M, Vellas B: Alzheimer's Disease Neuroimaging I: rationale for use of the Clinical Dementia Rating Sum of Boxes as a primary outcome measure for Alzheimer's disease clinical trials. Alzheimers Dement 2013, 9:S45-S55.

CDR-SB assesses cognitive impairment and is derived from ratings in six cognitive and functional domains, or boxes (memory, orientation, judgment and problem solving, community affairs, home and hobbies, and personal care). CDR-SB is the total score of all separate boxes (range 0 18 , with 0 as best score).

20. Hedden T, Oh H, Younger AP, Patel TA: Meta-analysis of amyloid-cognition relations in cognitively normal older adults. Neurology 2013, 80:1341-1348.

21. Ellis KA, Lim YY, Harrington $K$, Ames $D$, Bush Al, Darby $D$, Martins RN, Masters CL, Rowe CC, Savage G et al.: Decline in cognitive function over 18 months in healthy older adults with high amyloid-beta. J Alzheimers Dis 2013, 34:861-871.

22. Lim YY, Pietrzak RH, Ellis KA, Jaeger J, Harrington K, Ashwood T,

- Szoeke C, Martins RN, Bush Al, Masters CL et al.: Rapid decline in episodic memory in healthy older adults with high amyloidbeta. J Alzheimers Dis 2013, 33:675-679.

In 44 healthy older adults enrolled in the Australian Imaging, Biomarkers and Lifestyle Rate of Change SubStudy, high amyloid-beta was associated with greater decline in episodic memory measures over 6 months.

23. Villemagne VL, Pike KE, Chetelat G, Ellis KA, Mulligan RS, Bourgeat P, Ackermann U, Jones G, Szoeke C, Salvado O et al.: Longitudinal assessment of Abeta and cognition in aging and Alzheimer disease. Ann Neurol 2011, 69:181-192.

24. Lim YY, Ellis KA, Pietrzak RH, Ames D, Darby D, Harrington K, Martins RN, Masters CL, Rowe C, Savage G et al.: Stronger effect of amyloid load than APOE genotype on cognitive decline in healthy older adults. Neurology 2012, 79:1645-1652.

25. Junkkila J, Oja S, Laine M, Karrasch M: Applicability of the

- $\quad$ CANTAB-PAL computerized memory test in identifying amnestic mild cognitive impairment and Alzheimer's disease. Dement Geriatr Cogn Disord 2012, 34:83-89.

CANTAB paired associate learning (PAL) and CERAD Wordlist Learning delayed Recall could differentiate between normal aging, $\mathrm{aMCl}$ and $A D$, such that $84.5 \%$ of the cases were correctly classified. These results showed that CANTAB can be used for screening of AD-typical memory impairment.

26. Hampshire A, Highfield RR, Parkin BL, Owen AM: Fractionating -• human intelligence. Neuron 2012, 76:1225-1237.

In general intelligence, the higher-order factor $\mathrm{g}$ is accounted for by cognitive tasks co-recruiting multiple brain networks. Intelligence is an emergent property of three anatomically distinct cognitive domains (short-term memory, reasoning and verbal processing), each of which has its own capacity.

27. Sabb FW, Hellemann G, Lau D, Vanderlan JR, Cohen HJ, Bilder RM, McCracken JT: High-throughput cognitive assessment using BrainTest.org: examining cognitive control in a family cohort. Brain Behav 2013 http://dx.doi.org/10.1002/ brb3.158.

28. Brandt J, Sullivan C, Burrell LE 2nd, Rogerson M, Anderson A: Internet-based screening for dementia risk. PLOS ONE 2013 8:e57476. 
29. National Audit Office: Improving Services and Support for People with Dementia. London: Edited by Office TS; 2007, .. Available at: http://www.nao.org.uk.

30. Getsios D, Blume S, Ishak KJ, Maclaine G, Hernandez L: An

- economic evaluation of early assessment for Alzheimer's disease in the United Kingdom. Alzheimers Dement 2012, 8 : 22-30.

Although early diagnostic assessment and treatment has significant upfront costs, identifying $A D$ patients at an early stage results in cost savings and health benefits compared with no treatment or treatment in the absence of early assessment.

31. Weiner MW, Veitch DP, Aisen PS, Beckett LA, Cairns NJ, Green RC, Harvey D, Jack CR, Jagust W, Liu E et al.: The Alzheimer's Disease Neuroimaging Initiative: a review of papers published since its inception. Alzheimers Dement 2013, 9:e111-e194.

32. Ellis KA, Bush Al, Darby D, De Fazio D, Foster J, Hudson P, Lautenschlager NT, Lenzo N, Martins RN, Maruff P et al:: The Australian Imaging, Biomarkers and Lifestyle (AIBL) study of aging: methodology and baseline characteristics of 1112 individuals recruited for a longitudinal study of Alzheimer's disease. Int Psychogeriatr 2009, 21:672-687.

33. Visser PJ, Verhey FR, Boada M, Bullock R, De Deyn PP, Frisoni GB, Frolich L, Hampel H, Jolles J, Jones R et al.:
Development of screening guidelines and clinical criteria for predementia Alzheimer's disease. The DESCRIPA Study. Neuroepidemiology 2008, 30:254-265.

34. Selkoe DJ: Preventing Alzheimer's disease. Science 2012, 337:1488-1492.

35. Macaluso M, Krams M, Preskorn SH: Phase I trials: from traditional to newer approaches part II. J Psychiatr Pract 2011 , 17:277-284.

36. Macaluso M, Krams M, Preskorn SH: Phase I trials: from traditional to newer approaches. Part I. J Psychiatr Pract 2011, 17:200-203.

37. Barker AD, Sigman CC, Kelloff GJ, Hylton NM, Berry DA, Esserman LJ: I-SPY 2: an adaptive breast cancer trial design in the setting of neoadjuvant chemotherapy. Clin Pharmacol Ther 2009, 86:97-100.

38. Sperling RA, Krams M, Poole M, Lovestone S, Stern RA, Ropacki MT: Building an adaptive trial in AD: challenges and solutions. In Prevention of Alzheimer's Disease - What Will It Take?. Edited by Bain LJ. The New York Academy of Sciences Academy; 2013. eBriefings http://www.nyas.org/publications/ EBriefings/Detail.aspx?cid=2050c5d7-008b-4064-ab854c0a2be9ba52\# (accessed 8.10.13). 